\title{
KÖZIGAZGATÁS: TEGNAP, MA, HOLNAP ${ }^{1}$
}

\author{
(Administration: Past, Present, Future)
}

\section{LÖRINCZ LAJOS}

\section{Történeti áttekintés}

Közigazgatás ott jön létre, ahol közösségi ügyek jelentkeznek, olyan ügyek, amelyeket az egész társadalom magáénak érez, amelyek megoldásához az egész társadalom hozzájárulása szükséges. Azt hihetnénk, hogy ilyen alapon minden hordaállapotnál fejlettebb társadalomban kialakul valamilyen szintü közigazgatás. A dolog azonban nem így van, hosszú időn keresztül egyéni érdekek kiszolgálása céljából integrálódott nagyon sok olyan társadalmi eröfeszítés, amelyet ma közösséginek tartunk.

Ezért állíthatjuk, hogy a közösségi igazgatás elsö rendszerei, szinte 20. századi arculatot öltve, az öntözéses vízgazdálkodásra épülö társadalmakban alakultak ki, mindenekelött Kínában, Egyiptomban, de a Tigris és Eufrátesz völgyének államaiban is, ahol a pontosan megszervezett, az egész társadalmat átfogó közösségi munka tette lehetővé az egyre növekvő népesség alapvető szükségleteinek kielégítését. Az ókor legnagyobb, leggazdagabb és legerösebb államai azért lettek ilyenné, mert szakképzett, gondosan válogatott, érdemeiknél és nem születési elöjogaiknál fogva irányítói pozícióba jutott vezetöi réteg, mai kifejezéssel igazgatási elit, kormányozhatta az országot. A kínai civilizáció folyamatosságát és egyéni arculatát korán kiépült állami bürokráciájának köszönheti, s ugyanezt állapithatjuk meg az összes huzamosabb ideig fennálló ókori birodalomról (Gladden 1972; Heady 1979).

A közigazgatás rendszerének kialakulásához az első követelmény a közös ügyek, a közưgyek és a magánügyek közötti különbségek elismerése, à közös ügyek magasabb rendünek való minösítése a társadalom minden szintjén, különösen a társadalmi hierarchia csúcsán. A legkülönbözöbb elnevezésủ, de nagyjából azonos funkciókat gyakorló állami vezetők az ókori birodalmakban, ideértve a római, bizánci birodalmakat is, szabályként elkülönítve kezelték - amint azt Weber, Wittfogel (1957) és nyomukban mások részletesen kimutatták - a köz pénzeit és a magánvagyont, a köz feladatait és az egyéni célkitüzéseket. Mindezzel megteremtödik a második közös igazgatási sajátosság elvi alapja is: a horizontális és vertikális hierarchikus igazgatási struktúra. Nagy kiterjedésü birodalmak esetében a vertikális hierarchia a hatalomgyakorlás egységes rendjét biztosította, a horizontális pedig a munkamegosztás alapjait teremtette meg az állami ügyek intézésének legfontosabb területei, úgymint pénzügy, hadügy, gazdasági ügyek, építési ügyek között.

A hierarchikus felépítésböl kỏvetkezően a közigazgatás az ókori államokban centralizált, a döntési és irányítási jogosítványok a hierarchia csúcsán elhelyezkedöknél 
összpontosulnak. Az erós és jól megszervezett, hatékony közösségi ügyintézés általában despotikus kormányzási móddal párosul, vagyis a hatalom egykézben való tartásával, s olyan irányítási stílus alkalmazásával, amely kevésbé van tekintettel a célkitüzés és a megvalósítás dologi és személyi ráfordításainak arányára.

Eisenstadt (1963) centralizált történelmi bürokratikus birodalmaknak, vagy történelmi bürokratikus társadalmaknak nevezi azokat, ahol a közösségi ügyek intézésének ilyen modellje alakult ki, melyek más modellekkel szemben, mint - az ő terminológiaját használva - a primitív politikai rendszerek, a nomád vagy hódító birodalmak, a város-államok és a feudális rendszerek, sokkal eredményesebb, időt állóbb eredményeket könyvelhetnek el, mert bebizonyítják, hogy csak közigazgatási intézmények képesek a hatékony társadalmi ellenőrzésre, a társadalmi erőforrások fokozatos növelésére. A közigazgatás intézményesülése segített a kulönböző társadalmi csoportok közötti kapcsolatok stabilizálásában is.

Az európai feudalizmus a 7-8. századig bezáróan teljesen új helyzetet teremt a közösségi ügyek igazgatásának történetében. Korai szakaszában drasztikusan szakít a közösségi ügyek központi szervezésének gyakorlatával, azaz felszámolja a közigazgatást. A közősségi ügyek minimálisra csökkennek, s kielégítésükröl a legkisebb közösségek gondoskodnak. Eltünik a szervező állam is a közulgyek koncepciójával egyutt. A feudális rendszer csak a minimumát teljesíti mindannak, ami az alapvetỏen agrár társadalom túléléséhez szükséges. A kormányzó hatalom számos kis közősség között fragmentálódik, $s$ ezek is állandó konfliktusban állnak egymással az anyagi források megszerzéséért. Amint azt tudjuk, a konzekvencia az, hogy egészen a 11. századig a lakosság száma csökken, a mezőgazdasági termelés visszaesik, s általában a társadalmi kooperáció mértéke a minimálisra redukálódik.

Négy évszázados lassú fejlődés eredményeképpen kezd megváltozni a helyzet, amikor Európa egyes államaiban a 16-18. századra kialakulnak az abszolút monarchiák, melyeknek témánk szempontjából az az „újdonságuk”, hogy újra használják a közügyek fogalmát, és ezzel egylitt megteremtik az újkori közigazgatás kialakulásának alapját. Richelieu és Colbert Franciaországban, VIII. Henrik és Erzsébet Angliában, a brandenburgi választófejedelem és fia, I. Vilmos Frigyes, majd Nagy Frigyes Poroszországban, Mária Terézia és II. József az osztrák birodalomban az új közigazgatási koncepció és rendszer kialakításának vezéregyéniségei. Erre a rendszerre a centralizáltság mellett, a megnövekedett aktivitás a jellemzỏ. Megfogalmazódik a jelszó: mindent a közért, ha szükséges, a kőz ellenében is. A merkantilizmus, mint állami gazdaságpolitika, növelte az állami bevételeket, javította az alattvalók életkörưlményeit, út- és csatornaépítéseket, szabályok megfogalmazását, számtalan hivatal felállítását és hivatalnokok alkalmazását eredményezte. A középkori feudális adminisztrációval összevetve óriási mérvủ a változás: a középkori uralkodó saját birtokainak növelésével és védelmével, igazgatásával és irányitásával van lekötve, kiváltságainak örzésével a vele állandóan vetélkedö nemességgel és egyházzal szemben. A felvilágosult abszolutizmus uralkodói országukat, birodalmukat akarják gazdagítani. A középkori királyi tanácsok hivatalnokai a királyi udvar 
közönséges tagjai, egy sorban állnak a szakácsokkal, ételkóstolóval és az inasokkal. $\mathrm{Az}$ állami szolgálat szerencsétlenül összemosódott a királyi udvar magánszolgálatával. A felvilágosult abszolutizmus tisztviselöje egyetemet végzett, ahol igazgatástudományt, akkori elnevezéssel kameralisztikát tanult, versenyvizsga eredményeképpen, tehát képessége alapján juthatott be a közigazgatásba, ahol elöre kiszámítható karriert futhatott be (Heady 1979).

A nemzetállamok kialakulását, vagyis a polgári átalakulás korszakát a közigazgatást tekintve radikális ideológiaváltás jellemzi, anélkül azonban, hogy magának a közigazgatásnak a szerkezete megváltozna. Az ország többé nem a király tulajdona, hanem a nemzeté, $\mathrm{s}$ az állam az a gépezet, amelynek segítségével a nemzet létrehozza kormányát, szervezi a köz szolgáltatásait. A tisztviselő nem a korona szolgája többé, hanem az államé. A közhatalom nem egy személy eszköze. A köztisztviseló a jog elóírásainak megfelelöen jár el, nem egy személy kívánságai szerint, védelmet a jog azért nyújt számára, mert a jog a nemzeti akarat kifejeződése.

Más tekintetben a közigazgatásban csupán az azóta sem szünetelö átkeresztelések jelzik a változást: Napóleon a Királyi Tanácsot Államtanáccsá kereszteli át a szerv jellegének legcsekélyebb változtatása nélkül, $\mathrm{s}$ minden Napóleonnak tulajdonított alapelv, rend, hierarchia, specializáció és nyilvántartás, már évszázaddal vagy évezredekkel korábban megfogalmazódott.

Napjaink felé közeledve a közigazgatás történetének vizsgálatába bekapcsolódnak a közigazgatással foglalkozó tudományok, ettöl fogva a fejlödés leírásának egyöntetüsége megszünik, noha a közigazgatás egy és ugyanaz marad.

A kameralisztikáról már tettem említést, ez a diszciplína nem volt más, mint a gyakorlati közigazgatási tennivalók rendszerezett leírása, amely különösebb visszhang nélkül kikopott az egyetemi tanrendekból. Nem így a jogtudomány. A 19. század elejétöl kezdödően, Európában, annak is föleg kontinentális részében, a jogállamiság korai szakaszában, a szabad verseny klasszikus felfogását erósitve és azáltal erősödve a közigazgatás felé a társadalom igényeit egyre inkább és kizárólagosabban a jogtudományok közvetítik. Az alapelv jogtudományi közvetítéssel csak jogi formájú lehet: a közigazgatás csak azt teheti és csak úgy, amit és ahogyan azt a jogszabályok megengedik. A társadalmi ellenörzés, a képviseleti szerveknek, azaz a politikának az igazgatás fơlötti szupremációja, a közjog és a magánjog, áttételesen a közéleti etika elkülönültsége, az állam szerepének visszafogása egyaránt benne van e tömör követelményben. A jogszabályokat ebben az idöben a képviseleti szervek fogalmazták, amelyekbe egyre inkább politikai pártokhoz való csatlakozással lehetett bejutni, s e pártok valamilyen társadalmi réteget képviseltek. A parlamentek által elfogadott törvényekben a népszuverenitás fikciója fejeződik ki, a jog uralma alatt álló közigazgatás - a jogtudomány felfogása szerint - demokratikus, a lakosság részvételével megvalósított közérdekủ ügyintézés. A kontinentális Európa - majd látni fogjuk Anglia és fơként Amerika más álláspontot képvisel - a magánjog területén eltérỏ szabályt érvényesít: minden megtehető, amit a jog nem tilt. A jogállam közigazgatása gúzsba van kötve, a gazdálkodás, a kereskedelem, mai terminológiá- 
val a versenyszféra annál szabadabb. A közigazgatásnak a jogtudomány akkori felfogása szerint - ez egyébként megegyezett a korabeli uralkodó filozófiai, kőzgazdasági nézetekkel - pusztán az éjjeliör szerepét kell betölteni, azaz a közrendet kell fenntartani, és óvni kell az ország területi integritását az esetleges külsỏ támadásokkal szemben.

Az uralkodó elméletek azonban nem feltétlenül a valóságos folyamatokat túkrözik, hanem vagy az elméletgyártók szellemes világlátását, vágyait, olykor bizonyos rétegek érdekeit, kívánságát fogalmazzák meg. Esetünkben pl. szó sincs arról, hogy a közigazgatás társadalmi szerepe, jellege ténylegesen megváltozott volna. Aktivitása nem csökken, országonként más-más oknál fogva avatkozik be a különböző kereskedelmi, oktatási, népjóléti szakkérdések eldöntésébe. A folyamat jelei: a kormányzati szervezet további differenciálódása, a császár-kori Rómában kialakult öt ágazat (külügy, belügy, hadügy, pénzügy, igazságügy) mellé a népjóléti ügyek, oktatási, ipari és kereskedelmi, mezőgazdasági ügyek intézésére jönnek létre központi igazgatási szervek az „éjjeliőr" koncepciójú államstruktúrában. A kiválasztás, mint minden igényes és erős közigazgatási rendszerben továbbra is az érdemeken alapul. A dontések ésszerü döntéshozatali eljárás szerint születnek.

Nem ugyanez a helyzet ebben az időszakban - a 18-19. századnál tartunk - Angliában és különösen Amerikában. Amerika áll leginkább szemben a kontinentális európai megoldásokkal, ezért inkább az ottani sajátosságokat ismertetem. Amerika ebben az időszakban abban különbözik Európától, hogy nincs igazi közigazgatása, és nem is akar létrehozni ilyet. A telepeseknek - mivel nincs államuk - minden ügyet maguknak vagy a legszükebb környezetüknek, településüknek kell megoldani. Közügy, azaz a lakosság kiterjedt részét érintő, feltétlenül megoldásra váró ủgy nem lévén, természetesen ki sem alakulhatott a közigazgatás. Amerika hosszú idỏn keresztül nem abban különbözött Európától, hogy más közigazgatása volt, hanem abban, hogy nem volt közigazgatása. (A késöbb kifejlödött közigazgatás azonban nem tartalmaz lényeges eltéró vonásokat.)

Az államellenesség, a központi hatalom kialakításától, megerősödésétől való félelem, amely az amerikai alkotmányt megfogalmazókban, az „alapító atyák"-ban is megvolt, bizonyos mértékben ma is megvan az állampolgárok konzervatív beállítottságú rétegeiben, hallatlan mértékben növelte az önkéntes polgári társulások, a lakossági önszerveződések, az önkormányzás jelentőségét. Már-már úgy látszott sikerült a görög polisz rendszert kontinens nagyságú méretekben, mint a bürokratikus igazgatás ellenmodelljét felújítani és kiterjeszteni (nem véletlen, hanem tudatos hivatkozás a görög győkerekre a timpanonos, ion vagy dór oszlopos középületek archaizáló stílusa). Az önkormányzati modell, mint a lakosság önszerveződési készségét és szándékát kifejezỏ szervezeti forma azt kívánja meg legelöször, hogy a közösség minden tagjának egyforma esélye legyen a közös ügyek intézésére, ne alakuljon ki privilegizált réteg, amely e jogok gyakorlását monopolizálhatja. Képzettségi elöírások, rátermettség vizsgálata tehát szóba sem jöhetnek, a közhivatalt rövid ideig lehet betölteni a minél nagyobb mérvủ rotáció érdekében. A rotáció a pártoso- 
dás megerösödésével amúgy is elkerülhetetlen: minden évben sor kerül valamilyen választási kampányra, minden évben cserélődik a közfunkciót betöltők egy része, $\mathrm{s}$ velük egyưutt mindazok a rokonok, barátok, lekötelezettek, akiket a közfunkciók betöltöi jutalmaznak meg valamilyen szinekúrával. A patronázs rendszernek olyan torzulata alakult ki, amely a múlt század nyolcvanas éveire lehetetlenné tette az alapvetö közfunkciók szakszerü gyakorlását, maga az amerikai társadalom győződött meg a zsákmány-rendszer, vagyis a politikának odadobott igazgatási struktúra, másképpen a szakszerü igazgatás nélküli társadalomirányítás zsákutca jellegéről.

Az 1880-as évek az akkori fejlett világban egységes változást eredményeznek a közigazgatás területén. A szabályozatlan szabadverseny hátrányai egyre jobban kiütkőznek, a szociális feszültségek élesednek, szinte egyöntetủ a gyógymód meghatározása: erősebb állam, erősebb közigazgatás, az anarchikus gazdasági viszonyokban rendteremtés. A társadalomkutatók némelyike az államkapitalizmus, az imperializmus, másik része beavatkozó állam kialakulásának, ismét mások igazgatási forradalomnak írják le a korszakot, s egy dologban valamennyiüknek igaza van: világszerte megszünik a fenntartás az állami bürokráciával szemben, eppen azt kezdik keresni, elöször nagyüzemi méretekben az emberiség történetében, miként lehetne hatékonyabbá, eredményesebbé tenni. E jelenség mellett feltünik egy ellentétes tendencia is, amely azonban csak az első világháború után erősödik meg, a folyamat elején csak az alig olvasott múvekből ismerhetó meg az anarchista, szociáldemokrata, szocialista, kereszténydemokrata világnézetủ gondolkodók növekvö aggodalma a jelenség láttán.

$\mathrm{Az}$ eredményesség javításában Amerika próbálkozása tủnik a legeredetibbnek. Mivel ez az ország az egyeduuli, amelynek egészen a múlt század végéig nem volt igazi közigazgatása, olyanná próbálta azt formálni, amilyenek a nagyon is eredményes ipari nagyüzemek voltak. Ráadásul ebben az időben jelent meg Taylor könyve az ipari munka tudományos megszervezéséröl (Taylor 1911), amely tele volt olyan szervezési általánosításokkal, amelyek alkalmazhatónak tủntek a közigazgatásban: specializáció, koordináció, parancsteljesítés, a munkafolyamat részletes megtervezése stb. Ettől kezdve az amerikai, majd más országbeli megfigyelök számára is, akik az ipari munkaszervezést az egyedüli jónak és követhetónek, egyszóval modellnek tartják, a közigazgatás minden hibája abból származik, hogy eltér a modelltỏl, s gyorsan jól olajozott nagyüzemmé válhatna, ha idomulna az általánosnak feltuntetett ipari szervezési elvekhez. Az alapvetỏen gazdasági szemléletủ elmélet szerint amíg a piacot a verseny, a dinamizmus és a választás szabadsága jellemzi, addig a közigazgatást a monopol-helyzet, a stagnálás és a kényszerítő eró. A társadalom olyan mértékben válik dinamikussá, amilyen mértékben minden szervezete a piac törvényei szerint funkcionál.

A köz- és magánszféra elválasztására felépülő kontinentális Európa fintorogva fogadta az Amerikától származó újdonságokat, s néhány kivételtöl eltekintve tudomást sem vett róluk. Amikor a két világháború között egy-két szimpatizánsa és követője támad az amerikai eszméknek, az Újvilágban már modellt váltanak. Európában a 
jogrendet finomítják tovább, kidolgozzák a közigazgatási jogviszony elméletét, a közigazgatási aktustant, a kozigazgatási szerzödés intézményét, vagyis eszkőzöket keresnek a kőzigazgatás hatalmának kiteljesedéséhez. Az addig uralkodó büntető és polgári jog mellé felnö, söt terjedelemben és jelentóségében ezeken túlnő a kőzigazgatási jog.

A reál szféra tekintetében a helyzet ugyanaz az egész fejlett világban: a közszféra súlya megállás nélkül növekszik, legyen szó akár a szabadverseny büvöletéböl szabadulni még mindig nem tudó Amerikáról, vagy a köz- és a magánigazgatás különbségét továbbra is hangsúlyozó Európáról. Az Amerikai Egyesült Államokban pl. 1924-ben a bruttó nemzeti termelés 9,9\%-át fordították kormányzati kiadásokra, 1938-ban 19,7\%-át (Straussman 1990, 10).

Az első világháború, az ezt kơvető helyreállítási programok, a gazdasági világválság, majd a második világháborúra való készülödés mind nyilvánvalóbbá tették a végrehajtó hatalom, a kormányzati munka, a közigazgatás erösítésének szükségességét. Ez az egységes folyamat azonban eltérő filozófiákon alapult. A szovjet állam egyrészt társadalom-átalakitási terveire hivatkozhatott, amelyhez erös központi hatalomra, a közügyek körének soha nem tapasztalt kiszélesítésére volt szuukség. Másrészt kötötte egy ideológiai korlát, miszerint a szocialista társadalom végcélja a lakosságtól elkülönülő, elidegenedett állami, közigazgatási struktúra teljes felszámolása, az önigazgatás megvalósítása. A kiutat - eléggé értelmezhetetlen módon Sztálin fogalmazta meg: az állam elhalásához az állam megerösítésén keresztül vezet az út, ergo minél erősebb, annál közelebb áll az elmúláshoz. Az ebben az időben kialakult diktatúrákban, tehát a Szovjetunió mellett elöbb Olaszországban, később Németországban, de még a demokráciát védelmezö USA-ban is a törvényhozó hatalommal szemben erősítik a közigazgatást, egyaránt utalva a pártok uralta törvényhozás terméketlen vitáira, a demokrácia vadhajtásaira. Mindenhol erös végrehajtást, hatalmi koncentrációt, elnökhöz, pártvezérhez feltétlen engedelmességet valósítanak meg, illetve követelnek, a módszerekben és eljárásokban természetesen óriási különbséggel. A jogállam eszméje, illetve annak a közigazgatásra vonatkoztatott tétele Európaszerte háttérbe szorul, a jogszerüség követelményét megelözi az eredményességé, ami Amerikában a kezdetektöl így volt, éppen az üzemi szervezési modell csodálata miatt. A tudomány egy új irányzata azonban a szervezési csodareceptek gyakorlati alkalmazásának tapasztalatait elemezve megdőbbenéssel tapasztalja, hogy azoknak a közigazgatásban semmi hatása nincs. Teljesen mindegy, hogy a vezetés funkcionális vagy törzskari módját alkalmazzák, az eredmény sem nem jobb, sem nem rosszabb, kettős oknál fogva: egyrészt, mert a szervezetekben az informális emberi kapcsolatok sokkal jobban befolyásolják az eredményességet, mint a formális szervezési intézkedések; másrészt, mert a politika soha nem szünő hatalmi védőhálója a közigazgatás közưl a magánigazgatás elveit vagy alkalmazhatatlanná, vagy alig alkalmazhatóvá teszik (Simon 1945). Más szóval Amerikában is felfedezik - a második világháború elötti években járunk - a köz- és magánigazga- 
tás dichotomiájából fakadó, Európában három évszázaddal, Kínában három évezreddel korábban felfedezett következményeket.

A második világháború után - a várakozásokkal ellentétben - világszerte tovább nött a közhatalom szerepe a társadalom irányításában, ez a jelenség mind a mai napig töretlen. A specializáció tovább erösödik, a korábban adminisztratívmentes területek is, mint a tudomány, müszaki fejlesztés, sport, környezetvédelem igazgatási védnökségek alá kerülnek. A közigazgatási tisztviselök száma ugrásszerüen megnő, felkészültségük alaposabb, érdemi ügyintézői munkakörbe ma már egyetemi végzettség nélkủl nem lehet bejutni, ám a legfigyelemreméltóbb jelenség funkciójának szélesedése és kibővülése. Ha a 19. század közepén a rendészeti jellegủ tevékenység jellemezte leginkább, a század végétól a befolyásolás és beavatkozás, az ötvenes évektöl - már a 20. században - a gondoskodás. Gondoskodás a kiegyensúlyozott és elviselhető életkörülményekröl, beleértve az egészségmegóvást, a szociális támogatást, az oktatást, a lakásépítést, védelmet az ipari, környezeti ártalmak ellen, a pihenés, üdülés, szórakozás feltételeinek megteremtését stb., vagyis mindazoknak a feladatoknak az ellátását, amelyeket a jóléti állam fogalmával szoktunk összekötni. Csak néhány adat az elobbbiekben vázolt tendencia érzékeltetésére. Belgium 1965-ben a bruttó nemzeti termelés 32,3\%-át fordította kormányzati kiadásokra, 1984-ben 55,4\%-át. Franciaországban ugyanebben az időszakban az arányok 38,4\%-ról 52,7\%-ra módosultak, az Egyesült Királyságban 36,1\%-ról 47,8\%-ra (Straussman 1990, 11). Tudunk mindannyian arról, hogy az angolszász világban a nyolcvanas években - Reagen elnök és Thatcher miniszterelnök kormányzása idején kulminált a folyamat - végbement egy neokonzervatív ideológiával megalapozott, kifejezetten az állami bürokrácia visszaszoritására, a jóléti funkciók felszámolására irányuló „forradalom”, vagy sokak szerint „ellenforradalom”. Azt azonban - sajnos - már sokkal kevesebben tudják, hogy az államtalanítás csak szavakban történt meg. 1970 és 1991 között az Egyesült Államokban pl. a közszektor alkalmazottainak száma 13 millióról 18,5 millióra nőtt, ez több mint 42\%-os emelkedést jelent. A fóderális szervekben $8 \%$-os, a tagállamokban $64 \%$-os, a helyi szervekben $48 \%$-os a növekedés. A reál jelenségek és a politikai áramlatok, elméleti irányzatok egymástól elszakított bemutatása azért szúkséges, mert az elmúlt évtizedben szinte csak az utóbbiakról kapott tájékoztatást a magyar közvélemény, holott a reálfolyamatok egészen új irányba haladnak.

A második világháború utáni időszakot nemcsak a gondoskodó közigazgatás kifejlődése jellemzi, amely egyébként univerzális, társadalmi rendszereken átnövő jelenség, hanem a nemzetközi, nemzeteken felüli bürokrácia kialakulása is. Egész hadseregnyi alkalmazottja van az ENSZ-nek és különböző szerveinek, számuk csak az igazgatással foglalkozókat tekintve - meghaladja a 150 ezret, de az Európai Unió végrehajtó apparátusának a létszáma is több 17 ezernél. A nemzetközi bürokrácia nem csak azért új jelenség, mert korábban legfeljebb töredékesen volt tapasztalható, hanem, mert lényegével tartották ellentétesnek nemzetköziesedését, funkciója mindig valamely adott állam mükődtetésének biztositására szoritkozott. Nemze- 
tek fölőtti funkciók ellátására a politika internacionalizálódása következtében vállhatott alkalmassá.

Ezzel párhuzamosan figyelték meg az igazgatási rendszerek, struktúrák és eljárások alkalmazásának, átulttetésének korlátozott lehetőségét. Már a második világháború után elkezdỏdőtt egy-egy állam által kipróbált igazgatási struktúra átültetésének kísérlete valamely más államba. A szándék vagy humanitárius segítségnyújtás, vagy a demokrácia és az emberi jogok védelme, vagy a proletár internacionalizmus onzetlen célkitüzéseinek mezébe volt csomagolva, ténylegesen a megcélzott ország intézményrendszerének finom vagy erõszakos átalakítása a támogatást nyújtó állam kívánságainak megfeleló formára. Az Amerikai Egyesült Államok és a Szovjetunió volt e tekintetben a legsegítókészebb két ország, $s$ kudarcaik elemzése vezetett egy új diszciplína, az összehasonlító kőzigazgatás kialakitására. E diszciplína fö mondanivalóját abban összegezhetjük, hogy a bürokratikus szektor megváltoztatása más kulturális, politikai, gazdasági stb. - tényezók megváltoztatása nélkül eredmény nélkuili. A példák sokaságát lehetne felhozni a tétel helytállóságára, nem is a nyilvánvaló vagy baklövéseket hoznám fel, hanem a nyugat-európai országok ellenállását az amerikai business-szemléletü adminisztráció bevezetésével szemben kőzvetlenull a háború után, vagy a speyeri kőzpont történetét. Speyer, a francia megszállási zónába tartozván, francia ajándékként kapott egy ugyanolyan elitképzó intézményt, mint a de Gaulle által megalapított ENA. Ma a speyeri közigazgatási akadémia, anélkül, hogy bármilyen központi német korrekció történt volna, olyan mint egy tipikus német egyetem, $\mathrm{s}$ a történészeken, $\mathrm{s}$ a francia gaullistákon kívül senki sem ismeri a francia eredeteket. Igazán most látjuk tisztán az ellenkezö oldal példáit is: milyen felületes, vékony befolyást gyakorolt a sokkal totálisabb, agresszivebb szovjet expanzió a saját befolyásolási zónájában.

\section{A magyar közigazgatás rövid története}

Dióhéjban vázoltuk a közigazgatás fejlődését a világ mindenkori legfejlettebb régióiban, ez már maga jelentős torzulást eredményez, ugyanilyen rőviden mutatjuk be a magyar kőzigazgatás jelentősebb fordulópontjait.

A magyar közigazgatásról azt kell, mintegy összegzésként elmondani, hogy említésre méltó eredeti vonásokkal, mint az eddig említett nagy birodalmak, soha nem rendelkezett. Ilyeneket csak olyan történetírók tártak fel, akik más népek történetének ismeretében meglehetősen járatlanok voltak. A magyar közigazgatás modellkövető volt, szerencsésebb idószakokban a modell önként választott, a csillagzatok rosszabb állásánál ráero̊ltetett, s még utólag sem tudjuk pontosan megválaszolni, hogy mikor jártunk jobban. Követett valamilyen példát a magyar közigazgatás, de lemaradása a követett modelltől soha nem volt jelentỏs. Nézzuk rőgtőn a kezdeteket. A magyar államalapitás Géza és Szent István mủve volt. Magyarország két modell kỏzül választhatott, déli szomszédja, Bizánc rendkívül kifinomult, az elsó ezredforduló kőrul messze legrendezettebb, legszabályozottabb és pontosabb közigazgatási 
modellt ajánlott, nyugati szomszédja az éppen töredezö frank birodalom bajor hercegsége koraközépkori modellt, ahol igazából még nincsenek is közügyek, csak királyi magánügyek. A két modell között fejlettségben félezred év volt a különbség Bizánc javára. Nem lehetett kétséges, hogy elődeink, akik borzongással tekintettek a konstantinápolyi hierarchikus államigazgatási struktúrára, a fejlett nyilvántartási, ellenőrzési rendszerre, a felelősségrevonás gyakoriságára és következetességére, a Justiniánus által összeállított felfoghatatlan tartalmú törvénykönyv terjedelmességére, a 10. századbeli frank-bajor modellt választották, amely a koraközépkor adminisztrativ nadírját éppenhogy elhagyta. Olyan európai modellt választottunk tehát, amely nagyon elmaradott volt, de éppen ezért átvehető és alkalmazható a vérségi szervezetekből és a nemzetségi szokásjogból éppen csak kilépö magyar társadalomban (Hóman-Szekfü 1935). A lényeg azonban az, hogy Nyugathoz igazodtunk, s nem Kelethez, mert a bizánci társadalom akkorra már erösen át volt szöve keleti és despotikus elemekkel is, ezért a választás - noha erröl az Árpád kor különbözö jogállású vezetöi még évszázadokon keresztül nincsenek meggyőződve - szerencsés volt.

A második modellválasztás 1526 után adódik. A török modell a megszállt alföldi területeken, az éppen birodalommá összeállt Habsburgok uralma alatt álló osztráknémet modell pedig az ország északi részein kerül kötelezó jelleggel kipróbálásra. Az osztrák modell az erős központi hatalom, azaz a centralizáció és hivatásos hivatalnoki kar kiépítése szukkségességét hirdette, a török modell sokkal eröteljesebb decentralizációt, önkormányzati joggyakorlást engedélyezett. A török minta hatása tulajdonképpen még feldolgozatlan, de árulkodó jelnek tartható, hogy a másfél évszázados török kormányzás eredménye kb. 800 magyar nyelvben ragadt oszmántörök szó, $s$ ezek jókora része a közigazgatáshoz, $s$ annak funkcióihoz kapcsolódik (bilincs, csösz, tolmács, haramia, martalóc) ( $R$. Várkonyi 1985, 473).

Mindenesetre a Habsburg (osztrák) modellt néhány év hiján négyszáz évig próbálták minden elemében ránk kényszeríteni, sajnos csak részleges sikerességgel. A közigazgatás, hosszú-hosszú vajúdás után, amint arra az egyetemes közigazgatástörténetben utaltam a 16-18. században kezdett Európában római birodalmi szintre emelkedni, tehát a legjobb idöben csatlakoztunk volna a legélenjáróbb áramlatokhoz. A kuruc felkelésekből, a Rákóczi szabadságharcból, a reformkori mozgalmakból, 1848-ból, a Bach huszárok iránti egységes ellenszenvböl azonban kiolvashatjuk azt a tanulságot, hogy a magyar társadalom elsösorban nem az adminisztráció modernségét értékelte a Habsburg birodalom bekebelezési kísérleteiben. Pedig innentól számtalan igazgatási újítási tervröl lehetne hírt adni, melyek Franciaországban születtek, Poroszországon keresztül, Ausztrián át jutottak volna a 17. század végére teljes egészében Habsburg uralom alá került Magyarországra, ha itt jókora részük nem bukott voina meg a nemesi vármegyék ellenállásán. Maradt azonban egy terület, ehhez járulékosan csatlakozott másik kettö, amely alapjaiban osztrák birodalmi alkotásnak tekinthetö, modern volt és hatékony, a kiegyezés után lehetövé tette az ekkorra már anakronisztikussá váló megyei ellenállási tüzfészkek felszámolását, a közszolgálat korszerüsítését, 1920 után a teljes mértékben önállóvá váló magyar 
állam müködésének zavartalanságát: a pénzügyi igazgatásé. A pénzügyi igazgatást az alkotmányos kormány az abszolutizmustól változatlan formában átvette, meghagyta a számviteli és pénztári szolgálat, valamint az ügykezelés rendszerét (Magyary 1942). Ezért is van talán az a máig is jól érezhető minöségbeli különbség a magyar közigazgatásban a pénzulgyi és minden más igazgatási szektor között. Csak az érdekesség kedvéért jegyzem meg, hogy a fơvárosban az ostrom idején - a begyüjtő és kivégzó hordák mellett - csak a pénzügyi igazgatóságok müködtek zavartalanul, postázták az adó-befizetési felszólításokat.

A második világháborút követően - a közigazgatás története a saját útját járja igazából nem történt modellváltás. Szavakban és jelszavakban, ideológiában és célkitúzésekben persze gyökeresen megváltozott minden: a kormányból minisztertanács lett, az önkormányzatokból tanácsok, a polgármesterekböl tanácselnökök, a közigazgatásból államigazgatás, az államtitkárból miniszterhelyettes, a kezdetben csak a pénzügyi igazgatásban majd minden ágazatban érvényesülö kompetencia elvét azonban nem érte sérelem. A szocialista korszak az eredményesség és a hatékonyság, a feluulröl jóváhagyott tervezés és összehangolás princípiumain egységesen és kiszámíthatóan, nagyluzemszerủen müködő, szociális biztonságot nyưjtó, a legfelsöbb hatalom, amely ez esetben egy párt volt, utasításait késedelem nélkül teljesitö végrehajtó hatalmat - olyant amilyent Nagy Frigyes, Bismark, Taylor, Fayol elképzelt - szeretett volna létrehozni, a jogszerüség és a demokrácia kívánalmait, mint amelyek csökkentik az eredményességet, a gyorsaságot, a legföbb hatalom irányitásának hatékonyságát, kispórolva a rendszerböl. Ennek a korszaknak a sajátossága abban keresendö, hogy a külsö modell nem magasabb kulturális értéke, rejtett beolvasztási szándéka miatt nem tudott szervesülni a magyar társadalomban, az állami intézményekben, a közigazgatási rendben, hanem alacsonyabb vagy alacsonyabbnak tartott fejlettségi szintje miatt.

1989-90-ben a jogszerüségi elemek visszakerültek a magyar közigazgatásba, amely ismét modellválasztási kényszerhelyzet elé került. Szent István óta ismét szabadon és önként választhattuk meg melyik kényszerzubbonyba bújunk. Az ebben a kutatási szférában tevékenykedó társadalomkutatóknak köszönhetóen ismeretès volt a választék, $s$ ebböl politikusaink aktív közremüködésével olyan demokratikus állammodellt, benne közigazgatási modellt állitottunk össze, amely tartalmazta az amerikai, francia, olasz, akkor még nyugat-német, osztrák államfejlödés csúcstermékeit, egy-egy helyen kiegészitve a haladó magyar hagyományokkal. Ennek igazi értékéről még korai lenne beszélni, jellegzetességeit azonban már össze lehet foglalni.

Mindenekelött azt kell megemlíteni, hogy a hatékonyság és gyorsaság szempontjait nehezen találnánk meg a jelenlegi közigazgatási intézmények bármelyikének létrehozási indokai között. Az ellenkezöjére bőven lehet példát találni. Az önkormányzati törvény kifejezetten és tudatosan mellözött minden ésszerú gazdálkodásra vonatkozó megfontolást. A decentralizáció, a jogállamiság, az önállóság szavak szinte misztikus jelentőségúvé váltak. Ennek jegyében nyertek el önkormányzataink olyan nagymérvú autonómiát, amilyennel a világon egyetlen más helyi kormányzat 
sem rendelkezik, részesülnek önkormányzati képviselöink olyan tiszteletdíjban, amely kisebb településeken a községnek juttatott állami támogatás felét elviszi. A jogi fundamentalizmus jegyében szuletik olyan alkotmánybírósági határozat, amely kérkedésszerüen utasítja el a végrehajtás több milliárdos többletkiadásának mérlegelését. Az Országgyülés olyan törvényt fogad el a közalkalmazottak és köztisztviselök jogállásáról, amelynek több tízmilliárdos vonzatáról a törvény idevonatkozó részének hatályba lépése elött fél évvel szerez tudomást a pénzügyminiszter. A közigazgatási szervek határozatait olyan bírói rendszer keretei között és oly módon bírálják felül, amelynél költségesebbet és hosszadalmasabbat kitalálni sem lehetne, és még lehetne a példákat sorolni.

A közigazgatás-tudomány müvelöinek tíz évvel ezelött a magyar közigazgatás jogszerüségének javításáért, tevékenységi körének ésszerü szükítéséért kellett munkálkodniuk, most aggódva kell tapasztalniuk, hogy a jogállamiságnak az a múlt századbeli felfogása, amely nálunk a közigazgatás müködésének mércéjévé vált diszkreditálja a közigazgatást, alkalmatlanná teszi szolgáltató funkcióinak ellátására. A korszerú közigazgatás tevékenységében a jogszerüség és a célszerüség kritériumai összhangban állnak, a közigazgatás eddigi története számos példával igazolja milyen torzulások származhatnak akár egyik, akár másik kritérium mellözéséböl.

Nemcsak a célszerüség mellőzése gyengíti jelenlegi közigazgatásunkat, hanem az a dilemma is, amely az üzleti szabályokat erőteljesebben érvényesíteni akaró, amerikai-orientációjú, szervezéselméleti és a közigazgatás sajátosságait továbbra is hangsúlyozó, integritását és értékeit védeni szándékozó, nyugat-európai eredetú közjogi, politikatudományi szemléletmód különbségéból és a közöttük való választás kényszerébỏl adódik.

A szervezés vagy szervezetelmélet, illetve igazgatáselmélet szerint az igazgatás egy és ugyanazon elveken nyugszik, legyen szó akár az állam, akár egy ipari üzem szervező tevékenységéröl. Amint láttuk és még néhány mondat erejéig látni fogjuk, ezt az állitást magában az Amerikai Egyesült Államokban is megcáfolta a politikatudomány és a szociológia, az utóbbi években azonban újra erőre kapott, a gazdasági és szociális krízisböl való kilábalás egyik orvosságaként. Ha a köz- és a magánigazgatás között nincs különbség, sőt a mozgékonyság, a költségérzékenység a magánigazgatás mellett szól, miért ne lehetne a közigazgatási feladatokat uizleti vállalkozásoknak átadni, vagy miért ne végezné az állami adminisztráció funkcióit vállalatok módjára? A new public management mozgalma különösen Nagy-Britanniában, Új-Zélandon és Ausztráliában kapott nagy publicitást. A mozgalom gazdasági koncepciót követ: racionalizálás a szervezeten belül, privatizálás kifelé. A belsö racionalizálás a taylori elveket követi, sokan új-taylorizmusnak nevezik, teljesítménymérés, munkafolyamatok standarnizálása, veszteségforrások feltárása, létszámátcsoportosítás és karcsúsitás, verseny az egyes igazgatási egységek között. Az igazgatás ne csak a költségvetésböl müködjön, hanem szedjen használati illetéket, termeljen profitot, ne vállaljon újabb feladatokat, egyszóval alakuljon ki elégedett ügyfeleket kiszolgáló vállalkozó állammá. Óriási terv, amelyet az USA-ban az elnök- 
helyettes előterjesztésében nagy lelkesedéssel fogadott el a Kongresszus. Végrehajtásához azonban nem fogtak hozzá, mert a kongresszusi viszonyok kőzben megváltoztak. Nálunk azonban a tervet úgy ismertetik, mintha már meg is valósították volna.

A koncepciók kidolgozásában és paradigmaváltások sürgetésében gazdag szervezetelmélet a pénzügyi gazdálkodásban, a teljesítmény ősztönzésben nagyon sok sikertelen kísérletet erőszakolt ki, s a lelkesedés magas höfokát kellően értékelve mégis sokan úgy látják, hogy megrendeléseket a pozíciójukat megerösíteni kívánó politikusoktól és csúcstisztviselöktől kap, mert a kézhez kapott javaslatok alkalmasak az ơnmutogatásra, a vállalkozók szimpátiájának és ami ezzel együtt jár, anyagi támogatásának megnyerésére. Az „új” igazgatás retorikája a piacé, a versenyé, a vállalkozásé, $s$ aki vele szembeszáll, könnyen megkapja a bürokratikus ellenálló, képességhiányos bürokrata címkéket.

A nyugat-európai - fóként a német, francia, olasz, spanyol - szakirodalom és politikai gyakorlat erős fenntartásait hangsúlyozza az ,új” igazgatással szemben, s a kőzigazgatás klasszikus elveit állítja szembe: a szabályhoz kötöttség, hierarchia elvét. Az állami igazgatás számára alkalmazhatatlan a gazdaságban elfogadott kizárási elv, az állami szolgáltatás igénybevétele nem tehető fủggővé ellenérték fizetésétől. Vagy: az egyik egyén fogyasztása nem zárja ki másokét. Amíg a privát javak terjedelméröl, elosztásáról, egyéni preferenciákról a piac dönt, addig a közjavak elö́llításáról való dőntés politikai-adminisztrativ folyamat eredménye. A vállalkozói management olyan szolgáltatásokkal operál, amely csak a materiális javak elöállításával van összekötve, a közjó mint általános cél nem ösztönzi cselekvésre. A szúkösséget a közigazgatásban - állítják többen - nem lehet vállalkozói módszerekkel felszámolni. Saját belsö rendszerét kell fejleszteni, a költségvetés rendszerét, az államszámviteltant, a kőltségek felhasználásának ellenörzési módszereit. Szó szerint idézem Klaus König, speyeri rektor mondatait: „Félre kell tolni a vállalkozói szellem, a vállalkozói kultúra, a vállalkozási management retorikáját... Vannak közös vonások (a kơz- és magánigazgatásban) ... de nincsenek általánosan alkalmazható receptek. Ehhez nagyon is különbőzóek a történelmi kiindulópontok és a kulturális feltételek, különösen az Amerikai Egyesült Államok Civic-Culture-Administrationja és a kontinentális Európa klasszikus igazgatása között." (König 1995, 356)

A nyolcvanas évek végétől Magyarországon - a közigazgatást illetően - elöször az igazgatás demokratikus deficitjét kellett megszüntetni, ennek keretében az igazgatás alkotmányjogi átértékelödése következett be, erös igazgatási bíráskodással, részletes szabályozással, a tisztviselöi kar politika-mentesítésével. A második fázis igazából most kezdödik: a gazdasági-hatékonysági stratégia meghatározása, olyan részkérdések tisztázásával, mint a társadalmi probléma-megoldási felelősségnek az állami cselekvési zónából a magán cselekvési szférába való áthelyezése, az áthelyezés mértéke, ütemezése. A legfontosabb területen, a vagyonprivatizálásban a folyamat elkezdődőtt, a feladatprivatizálásban, bizonyos állami funkcióknak magánszervezetekkel tőrténő ellátása (contracting out), dereguláció, szubvenció leépités, létszámcsőkkentés, még csak a körvonalak kezdenek kirajzolódni. Mint ahogy az egy- 
oldalú jogi szemlélet gátja lehet a közigazgatás kiegyensúlyozott müködésének, az ökonómiai szemlélet olyan felfogása, amelyik a vállalkozói, a magánigazgatási módszerek átvételét tekinti a közigazgatás hatékonyságának javítására egyedül elképzelhetőnek, meggátolhatja a valóban eredményes módszerek elterjedését. A versenyszellem az erőseknek teremt kedvező müködési környezetet, a gyengéket kiszolgáltatja a profit elnyerésében kíméletlen módszereket, másfajta magatartási szabályokat érvényesnek tartó vállalkozói managementnek. A társadalmi szolgáltatásokat nyújtó közigazgatás ezzel szemben az egyenlő elbánás általános elve mellett a gyengébbek és kiszolgáltatottak pozitív diszkriminációjának különös szabályát alkalmazza, azaz a kiszoritás és gyözelem helýett a társadalmi igazságosság, a méltányos elbánás, a legalitás Európában megfogalmazott hagyományos kritériumait.

Csak utalásszerủen említeném meg a vállalkozói és a közcélú igazgatási szférában érvényesülö erkölcsi normák eltérőségét és az ebből származó konfliktusokat. A köztisztviselők és a közélet szereplöinek etikai normái sokkal zártabbak, kötöttebbek és szigorúbbak, mint a magánigazgatásban. A vállalkozói management tevékenységét, eljárását sokkal kevesebb tilalomfa határolja be, az üzleti élet protokolláris szabályainak keretei között megajándékozhatják egymást, kölcsönös megegyezéssel feltételeket módosithatnak, határidőket kitolhatnak, bekebelezhetik a versenytársat stb. A közigazgatásban az ajándékozásnak már az ígérete is megvesztegetésnek számít, a feltételek - a törvény erejénél fogva - a közigazgatást is kötik, a partneri együttmüködés kötelezettsége egyenesen tiltja az ügyfél létkörülményeit veszélyeztetö döntés végrehajtását. Az elmúlt években jó néhány sikeres üzleti vállalkozó került be az Amerikai Egyesült Államoktól kezdve Franciaországon, Olaszországon, Ausztrián át Magyarországot bezáróan a közigazgatás magas és legmagasabb pozícióiba azzal a céllal, hogy a közigazgatásban is bebizonyítsák az új, sikeresebb igazgatási filozófia és etika alkalmazhatóságát. Mondanivalónk szempontjából nem is az az érdekes, hogy ez nem sikerült, hanem az, hogy az általuk képviselt értékrend és etikai norma mindenhol elviselhetetlennek bizonyult mind a politikusok, mind a lakosság, a társadalom számára. Gyors távozásukat a kormányzásból nem szakmai sikertelenségük, noha olykor az is bebizonyosodott, hanem a közéletben megengedhetetlennek tartott, a vállalkozói managementben kialakult etikai felfogásuknak köszönhetik.

\section{Közigazgatás és politika}

A jogi szabályozás szükségessége és a túlszabályozás szükségtelensége, a gazdaságosság belsỏ, közigazgatásban érvényesíthető módjainak elótérbe kerülése, az agresszív és más célokat követö piaci management kritikai értékelése mellett harmadik, ugyanígy a szuikséges és szükségtelen határmezsgyéjén mozgó elem a közigazgatás és a politika helyes kapcsolatának a kialakítása.

A politika, a politikai pártok tisztában vannak a közigazgatás társadalmi jelentőségével. Tudják, hogy az állam javarészt közigazgatás, $s$ minden politikai célkitüzés 
csak a közigazgatás közremúködésével valósítható meg. Azt is állíthatjuk, hogy minden politikai küzdelem igazi célja a végrehajtó hatalom megszerzése. Bebizonyosodott azonban, hogy a politika túlhatalmasodása a közigazgatáson vagy az állami adminisztráció elsorvadását, vagy a politika elbürokratizálódását eredményezi. Ezért közös eröfeszítéssel kialakítottak egy határvonalat, aminek egyik oldala fenntartás nélkül a politika birodalmához tartozik, a másikon a kőzigazgatás szakmai, belsó szabályai érvényesülhetnek. A vonal természetesen kortól, az uralkodó politikai rendszer jellegétől függően mozog egyik vagy másik terrénum irányába. Minden rendszerben és minden időben közősen és kizárólagosan érvényesül a vezetői tisztségek politikai hüség vagy szolgálat alapján történỏ betơltésének elve. Úgy túnik, mintha ezzel a politika szerénysége, visszafogottsága fejeződne ki, de ha belegondolunk, hogy a hierarchia elvére épülö igazgatásban a hierarchia csúcsán elhelyezkedő személy vagy személyek csoportja az egész közigazgatással rendelkezik, akkor reálisabban értékelhetjük a megoldás jelentőségét.

Ez a rejtett mohóság, mert a már említett szerénység inkább ennek nevezhetö, azonban a közigazgatás integritásának egyedüli garanciája is. A politika akadályozza meg mindazoknak a veszélyeknek a felerősödését, amelyet Marxtól és Max Webertől kezdve szociológusok tơbb nemzedéke felidézett a bürokrácia öncélúságáról, a hatalom növekedésének megállapithatatlanságáról, elkülönült kaszt kialakulásának veszélyeiről. A politika, szupremációjának megörzésére tőrekedve, szoros gyeplö alatt tartja a közigazgatást, ezzel egyrészt meggátolja, hogy az saját célokat alakítson ki, másrészt megakadályozza, hogy a közigazgatás helyett bármilyen más társadalmi alakulat gyakorolja a közérdekú tevékenységet. Ha a magán-vállalkozói management filozófia és gyakorlat fékezhetetlen mohóságára gondolunk, örülhetünk, hogy létezik egy jelentős társadalmi erö, a politika, amely ugyan önös érdekeket kővetve, de gátját állja egy más irányú veszély kiteljesedésének, annak, hogy az állami szervezetek magáncélok megvalósitása érdekében tevékenykedjenek.

\section{A közigazgatás jövôje}

A kőzigazgatás jỏvőjéról bizonyossággal lehet azt állítani, hogy létezésének oka, a kőzősségi ügyek, $\mathrm{s}$ azok intézésének igénye tovább erősődik. A közősségi feladatok, a népesség vészes nővekedése, a termelési folyamatok belső komplexitásának erősődése, a nemzeti keretek fơlé kiépủlö, a jelenségek globalizálódását követő nemzetkőzi igazgatás kialakulásának kényszere, az urbanizációs folyamatok folytatódása a közigazgatás erősitését, munkájának további javítását kívánja meg. A kis állam vágya illuzórikus, noha bizonyos előnyökkel jảrna, egészében véve azonban társadalmi anarchiát eredményezne. Erös organizatórikus és szolgáltató feladatokat ellátó kơzigazgatás, szigorú társadalmi ellenőrzés alatt, öntevékeny civil szervezetek aktiv mükődése mellett oldhatja meg mindazokat a feladatokat, amelyekkel a különbözó államok, államszővetségek, az emberiség a közeli és távoli jövőben szemben találja magát. 
A másik kérdés, amelyik felvetódik: vajon mennyiben változik a jelenlegihez képest a közigazgatás? Számos nemzetközi konferencián, tanácskozáson vitatták meg a kérdést, a válasz többnyire azonos volt: jobb lesz, azaz pontosabb, gyorsabb, megértöbb, egyưuttmúkơdésre készebb, az állampolgár közremủkődésére jobban számító stb. Mindezt azzal éri el, hogy szervezete áttekinthetőbb lesz, a belső feladatelosztás ésszerúbb, tisztviselöi pedig felkészulttebbek. Ha a jövendőlések értelmezésébe mélyebben belemegyuink, akkor azt mondhatjuk, $s$ mindez összhangban van azzal, amivel tanulmányomat kezdtem, $s$ amit végig bizonyitani szerettem volna: a közigazgatás a jövőben is lényegében változatlan marad. Ezt igazolhatják azoknak a tervbevett reformoknak a kudarcai is, amelyek a hierarchikus szervezet helyett mátrix szervezetet próbáltak kialakitani, a rátermett és képzett tisztviselök helyett laikusokkal, társadalmi szervek tagjaival szerették volna a közfeladatokat ellátni. A kőzigazgatás eddigi tơrténete azt a föként zoológusok, ökológusok, kultúrantropológusok által megfogalmazott tételt látszik igazolni, hogy nem egyedul a változás a túlélés garanciája, hanem olykor a változatlanság is.

Azt azonban mégis túlzás lenne állitani, hogy a mai és a jövöbeni kőzigazgatás és a korábbi korszakok kőzigazgatása között nem lenne semmiféle kimutatható külơnbség. A közigazgatásban kiépített informatikai rendszerek, a számítógépen tárolt és továbbított ún. elektronikus ügyiratok egészében véve pontosabbá, gyorsabbá teszik azt a munkát, amelyet kezdetben selyemszalagokon, papirusztekercseken, agyagtáblákon, késóbb papíríveken lúdtollal, golyóstollal, írógéppel végeztek, s sơtét, rossz levegỏjü helyiségekben tároltak, s igen-igen nehezen tudták megtalálni, ha a dokumentumra szưkség volt. Hogy a technikai háttér javulása eredményez-e valóban minöségi változást is, a teruletünkờn folyó gyér jövőkutatások vitái még nem derítették fel. Tény, hogy a századfordulón megjósolt új igazgatási világ nem következett be, a két világháborủ között kibontakozni készülö posztindusztriális társadalom meröben más közigazgatási világa nem állt elö, $s$ ezért talán nem alaptalan azt állítani, nehezen képzelhető el, hogy az emberi kultúra négy-ötezer éves, szervesen és egy rővid időszakban tudatosan épülö intézménye helyett a közősségi ügyek intézésének a maitól győkeresen eltérö rendszere épửjön ki.

\section{Jegyzet}

' A tanulmány eredeti szơvege Szentpéteri István szuletésének 70. évfordulójára kiadott Emlékkőnyvben jelent meg 1996-ban (Szeged, 341-357. 0.).

\section{Irodalom}

Eisenstadt, S.N. (1963) The Political Systemes of Empires. New York, Free Press of Glencoe.

Gladden, E.N. (1972) History of Public Administration. London, Volume H-II.

Heady, F. (1979) Public Administration: a Comparative Perspective. New York-Basel.

Hóman B.-Szekfü Gy. (1935) Magyar történet. I. kótet. Budapest, Királyi Magyar Egyetemi Nyomda.

Konig, K. (1995) „Neue” Verwaltung oder Verwaltungsmodernisierung: Verwaltungspolitik in den 90er Jahren. - Die Offentliche Verwaltung. 9. 356. o.

R. Várkonyi Á. (szerk.) (1985) Magyarország története 1526-l686. I. kőtet. Budapest, Akadémiai Kiadó. 
Magyary Z. (1942) Magyar közigazgatás. Budapest, Egyetemi nyomda.

Simon, H.A. (1945) Behavior of Decision Making. New York, Macmillan.

Straussman, J.D. (1990) Public Administration. New York, Longman.

Taylor, F.W. (1911) Scientific Management. New York, Harper.

Wittfogel, K.A. (1957) Oriental Despotism: a Comparative Study of Total Power. New Haven, Yale University Press.

\section{ADMINISTRATION: PAST, PRESENT, FUTURE}

\section{LAJOS LÖRINCZ}

Administration - where built up - is unchanged from ancient times until recently, and it is expected not to be changed in the future even. Differences are only emerged from the different approaches of works about administration and the judgement of communal and individual values. Real processes prove that strong administration develops where public interest has a high priority - either for prime necessities, or for other reasons (Egypt, Chine, the states of enlightened absolutism). Administration hasn't been established (the states of early feudalism) or has developed abort (the city-states of ancient Greece, America in the 17-19 centuries) in societies, individual values were favoured in which. The world has became uniform for today: the administration, i.e. the role of governing in favour of public interest is increasing without stopping in real life, despite of every opposite literary, political, intellectual and entrepreneurial community of interests, request, demand, deliberate action supported by international criminal gangs. It's because of the world globalisation and the increasing complexity of social problems.

In this respect Hungary follows the general trend of development. So it wouldn't be right to value it differently with regard to the turbulence of groupings with egoistic interests presented previously. 